\title{
Pesticide Toxicity Profile: Ethylenebis (dithiocarbamate) Pesticides ${ }^{1}$
}

Frederick M. Fishel ${ }^{2}$

This document provides a general overview of human toxicity, provides a listing of laboratory animal and wildife toxicities and a cross reference of chemical, common and trade names of ethylenebis (dithiocarbamate) (EBDC) pesticides used as fungicides registered for use in Florida.

\section{General}

As a chemical family, the EBDC pesticides are regarded as fungicides with a wide range of uses including control of early and late blights of potatoes and tomatoes and many other diseases of vegetables, fruit, commercial sod, and field crops. They are also used as seed treatments. Nabam has biocide uses for control of slime-forming fungi and bacteria in industrial processing water systems and industrial lubricants. They have been on the market since the 1930s and 40s. Members of this chemical family that remain on the market in the U.S. include mancozeb, maneb, metiram, and nabam. Product formulations of mancozeb are dry flowables, flowables, wettable powders, and microencapsulated. Mancozeb is a coordination product of zinc ion and maneb. Maneb is available as a flowable formulation from several different manufacturers. Metiram is sold as a dry flowable formulation with a relatively small number of crop sites approved for use in Florida.

\section{Toxicity}

These fungicides may cause irritation of the skin, respiratory tract, and eyes. Maneb has been reported to be responsible for some cases of chronic skin disease in occupationally exposed workers, possibly by sensitization. Systemic toxicity by oral and dermal routes is generally low. Metiram is considered to have moderate acute toxicity. It is not significantly absorbed through the skin. Of the EBDC members, nabam shows the greatest toxicity, probably due to its greater water solubility and absorbability. Maneb is moderately soluble in water, but mancozeb is essentially water insoluble; therefore, skin absorption of these two active ingredients is probably very limited. In 1987, the EPA conducted a special review of the EBDC compounds because of concerns about the potential health effects from dietary exposure to residues left on food crops and occupational exposure.

1. This document is PI-64, one of a series of the Pesticide Information Office, Florida Cooperative Extension Service, Institute of Food and Agricultural Sciences, University of Florida. Original publication date September 2005. Visit the EDIS Web Site at http://edis.ifas.ufl.edu.

2. Frederick M. Fishel, Associate Professor, Agronomy Department, and Director, Pesticide Information Office; Florida Cooperative Extension Service, Institute of Food and Agricultural Sciences, University of Florida, Gainesville, FL 32611.

The use of trade names in this publication is solely for the purpose of providing specific information. UF/IFAS does not guarantee or warranty the products named, and references to them in this publication does not signify our approval to the exclusion of other products of suitable composition. Use pesticides safely. Read and follow directions on the manufacturer's label.

The Institute of Food and Agricultural Sciences (IFAS) is an Equal Opportunity Institution authorized to provide research, educational information and other services only to individuals and institutions that function with non-discrimination with respect to race, creed, color, religion, age, disability, sex, sexual orientation, marital status, national origin, political opinions or affiliations. U.S. Department of Agriculture, Cooperative Extension Service, University of Florida, IFAS, Florida A. \& M. University Cooperative Extension Program, and Boards of County Commissioners Cooperating. Larry Arrington, Dean 
It was concluded that the actual levels of EBDC

residues on produce purchased by consumers are too

low to affect human health. Many home garden uses

of EBDCs have been cancelled because the EPA

assumed that home users of these pesticides do not

wear protective clothing during application. Systemic poisonings of humans have been extremely rare. No tests for these fungicides or their breakdown products in body fluids are available. Mammalian toxicities for the EBDC fungicides are shown in Table 1. Table 2 lists the toxicities to wildlife by the common name of the pesticide. Table 3 provides a cross listing of many of the trade names that these products are registered and sold by in Florida.

\section{Additional Information}

Crop Protection Handbook. 2005. vol. 91. Willoughby, Ohio: Meister Publishing Co. http://www.meisterpro.com/mpn.

Nesheim, O.N. 2002. Toxicity of pesticides.

UF/IFAS EDIS Document PI-13.

http://edis.ifas.ufl.edu/PI008.

Reigart, J.R. and J.R. Roberts. 1999. Recognition and management of pesticide poisonings, $5^{\text {th }} \mathrm{ed}$. United States Environmental Protection Agency Publication EPA-735-R-98-003.

Seyler, L.A., et.al. 1994. Extension toxicology network (EXTOXNET). Cornell University and Michigan State University. http://extoxnet.orst.edu/index.html. Visited September 2005. 
Table 1. EBDC fungicide mammalian toxicities ( $\mathrm{mg} / \mathrm{kg}$ of body weight).

\begin{tabular}{||l|l|l||}
\hline \hline Common name & Rat oral LD $_{\mathbf{5 0}}$ & Rabbit dermal LD $_{\mathbf{5 0}}$ \\
\hline Mancozeb & $>5,000$ & $>5,000$ \\
\hline Maneb & 7,990 & $>5,000$ (rat) \\
\hline Metiram & $>6,810$ & $>2,000$ (rat) \\
\hline Nabam & 395 & --- \\
\hline \hline
\end{tabular}

Table 2. EBDC fungicide wildlife toxicity ranges.

\begin{tabular}{|c|c|c|c|}
\hline Common name & Bird acute oral LD ${ }_{50}(\mathrm{mg} / \mathrm{kg})^{\star}$ & Fish $(p p m)^{\star \star}$ & $\mathrm{Bee}^{\dagger}$ \\
\hline Mancozeb & PNT & ST - MT & PNT \\
\hline Maneb & ST & MT & PNT \\
\hline Metiram & PNT & ST & PNT \\
\hline Nabam & PNT & MT - HT & PNT \\
\hline \multicolumn{4}{|c|}{$\begin{array}{l}\text { Bird } \mathrm{LD}_{50} \text { : Practically nontoxic }(\mathrm{PNT})=>2,000 ; \text { slightly toxic }(\mathrm{ST})=501-2,000 ; \text { moderately toxic }(\mathrm{MT})=51- \\
500 ; \text { highly toxic }(\mathrm{HT})=10-50 ; \text { very highly toxic }(\mathrm{VHT})=<10 . \\
{ }^{\star} \text { Fish } \mathrm{LC} \mathrm{C}_{50}: \mathrm{PNT}=>100 ; \mathrm{ST}=10-100 ; \mathrm{MT}=1-10 ; \mathrm{HT}=0.1-1 ; \mathrm{VHT}=<0.1 . \\
{ }^{\dagger} \mathrm{Bee}: \mathrm{HT}=\text { highly toxic (kills upon contact as well as residues); } \mathrm{MT}=\text { moderately toxic (kills if applied over } \\
\text { bees); } \mathrm{PNT}=\text { relatively nontoxic (relatively few precautions necessary). }\end{array}$} \\
\hline
\end{tabular}

Table 3. Cross reference list of common, trade and chemical names of EBDC fungicides.

\begin{tabular}{||l|l|l||}
\hline \hline Common name & Trade names* $^{*}$ & Chemical name \\
\hline Mancozeb & $\begin{array}{l}\text { Rainshield } \AA \text {, Dithane } \AA \\
\text { Penncozeb } \AA\end{array}$ & $\begin{array}{l}\text { Coordination product of zinc ion, manganese } \\
\text { ethylenebis(dithiocarbamate) }\end{array}$ \\
\hline Maneb & Manex $\AA$ & Manganese ethylenebis(dithiocarbamate) \\
\hline Metiram & Polyram $\AA$ & $\begin{array}{l}\text { Tris[ammine-[ethylene } \\
\text { bis(dithiocarbamato)]zinc(II)[tetrahydro-1,2,4,7- } \\
\text { dithiadiazocine-3,8-dithione] polymer }\end{array}$ \\
\hline Nabam & Disodium ethylenebis(dithiocarbamate) \\
\hline *Does not include manufacturer's prepackaged mixtures. \\
\hline \hline
\end{tabular}

